(C) Kuroiedova V. D., Petrova A.V., Rud Y.V.

UDC 616.314-089.23-085

DOI https://doi.org/10.31718/mep.2019.23.3-4.08

\title{
EUROPEAN POSITION ON CLINICAL PRACTICE OF EXTRACTION AND NONEXTRACTION THERAPY IN ORTHODONTICS
}

\author{
Kuroiedova V. D., Petrova A.V., Rud Y.V. \\ Ukrainian Medical Stomatological Academy, Poltava
}

Ортодонтичне лікування в будь-якому віці - це тривалий і складний процес, що вимагає комплаєнції між лікарем $і$ пацієнтом, трудомісткість і комплексність, складність і тривалість якого з переходом від молочного до постійного прикусу зростають. Важливим фактором у прийнятті рішення про початок ортодонтичного лікування $\epsilon$ його з кожним днем зростаюча вартість, причиною якої $\epsilon$ прихід в щоденну практику сучасного лікаря-ортодонта новітніх дорогих технологій і конструкцій, а, найголовніше, переведення стоматології в цілому і ортодонтії, зокрема, в приватний сектор. Способів скорочення термінів ортодонтичного лікування декілька: в періоді зміни зубів - це прийоми корекційного видалення зубів, засновані на різниці мезіально-дистальних розмірів молочних молярів та премолярів, які приходять їм на зміну, метод Hotz, в постійному прикусі - це видалення окремих здорових зубів відповідно до обраної стратегії лікування порушень прикусу, компактостеотомія, застосування різних фізіотерапевтичних методів без лікарських препаратів і з вживанням засобів, що сприяють послабленню кісткової тканини в поєднанні з активною дією фізичних факторів та інші, пов'язані з удосконаленням ортодонтичних конструкцій. Найбільш значущим чинником в ортодонтичному лікуванні, що приводить у великій кількості випадків до переривання корекційного процесу, є його тривалість, що досягає в періоді постійних зубів 2-3 років. Ще одна серйозна проблема в ортодонтичному лікуванні, безпосередньо пов'язана з питанням стратегічного вибору екстракційного або безекстракціонного методу лікування - це стабільність отриманих клінічних результатів. Тільки грамотне лікарське прогнозування стабільних морфологічних і функціональних клінічних успіхів ортодонтичного лікування може бути науковою і моральною основою для вибору стратегії ведення ортодонтичного пацієнта із застосуванням видалення окремих (одного і декількох) здорових зубів. Тому проблема скорочення термінів ортодонтичного лікування як у дітей, так і у дорослих - одна з найважливіших в корекції прикусу в будь-якому віці. Саме тому в комплексному ортодонтичному лікуванні хірургічні заходи займають значне місце. Видалення окремих постійних зубів - це відповідальне узгоджене рішення між пацієнтом і лікарем-ортодонтом, яке повинно бути індивідуальним з урахуванням безлічі факторів. Зі збільшенням кількості пацієнтів в періоді молочного прикусу лікар повинен бути підкований теоретичними знаннями і сучасними напрямками в особливостях ортодонтії зростаючого дитячого організму. Незважаючи на довгі десятиліття застосування в ортодонтичному лікуванні хірургічного прийому видалення здорових зубів, в європейській науковій літературі вибір екстракційного або безекстракційного методу лікування як і раніше є дискутабельним. Нові діагностичні методики, вдосконалені ортодонтичні конструкції, національні особливості будови лицьового черепа і багато інших сучасних поглядів дуже потрібні для правильного формування європейського мислення у ортодонта.

Ключові слова: видалення зубів за ортодонтичними показаннями, екстракційний, безекстраційний методи лікування

Orthodontic treatment is a long-lasting and difficult process which requires compliance between doctor and patient. It is a complex process, duration of which increases with transition from temporary to permanent bite. The main factor of orthodontic treatment is the cost of the procedure because there are new and modern tools and equipment. There are several ways to reduce orthodontic treatment: in the period of changing teeth, these are methods of corrective teeth extraction, based on the difference in the mesial-distal dimensions of milk (temporary) molars and method Hotz, replacing them with premolars, is the removal of individual healthy teeth according to the chosen treatment strategy bite disorders, compact osteotomy, the use of various physiotherapeutic methods without drugs and with the use of agents that promote bone tissue relaxation in combination with active physical factors and others related to the improvement of orthodontic appliances. The most significant factor in orthodontic treatment, resulting in a number of cases of interrupting the correction process, is its duration, up to 2-3 years in the period of permanent teeth. One more serious problem in orthodontic treatment associated with strategic choice of extraction or nonextraction method of treatment is stability of received clinical results. Only therapeutic prognosis of stabile morphological and functional clinical advantages of orthodontic treatment can be a basis for choice of orthodontic treatment management with the use of extraction of some healthy teeth. So, the problem of orthodontic treatment both in children and adults is one of the most important in bite correction. That's why surgeries are involved in complex orthodontic treatment. Extraction of some permanent teeth is coordinated decision between patient and orthodontist considering the number of factors. Orthodontist must be theoretically competitive in the peculiarities of child's organism. Despite the use of surgery of healthy teeth in orthodontic treatment in European and scientific literature the choice of extraction and nonextraction method of treatment has been yet discussable. New diagnostic methods, modern orthodontic appliances, national peculiarities of face and other features are needed for correct European thought in orthodontist.

Key words: extraction of teeth of orthodontic indices, extraction, non-extraction methods of treatment.

To cite this english version: V. D. Kuroiedova, A.V. Petrova, Y.V. Rud. European position on clinical practice of extraction and nonextraction therapy in orthodontics. . // The Medical and ecological problems. - 2019. - Vol 23, № 3-4. - P. 32-36. 
The evaluation of dynamics of orthodontic treatment of patients of different age was done one the Department of Postgraduate Education of Orthodontists for recent 18 years (2000-2018) (Tab. 1).

Table 1.

Dynamics of activity of orthodontic patients of different age (2000-2018)

\begin{tabular}{|c|c|c|c|c|c|c|c|c|}
\hline \multirow{2}{*}{ Age structure } & \multicolumn{2}{|c|}{2000} & \multicolumn{2}{|c|}{2007} & \multicolumn{2}{|c|}{2013} & \multicolumn{2}{|c|}{2018} \\
\hline & $\mathrm{n}$ & $\%$ & $\mathrm{n}$ & $\%$ & $\mathrm{~N}$ & $\%$ & $n$ & $\%$ \\
\hline Up to 6 years & 15 & 1.4 & 4 & 0.8 & 37 & 2.63 & 42 & 5 \\
\hline $6-9$ years & 71 & 6.7 & 39 & 7.6 & 497 & 35.35 & 340 & 38 \\
\hline $10-13$ years & 476 & 44.8 & 237 & 46.1 & 304 & 21.62 & 166 & 19 \\
\hline $\begin{array}{l}\text { Children over } 13 \text { years } \\
\text { old }\end{array}$ & 501 & 47.1 & 234 & 45.5 & 568 & 40.4 & 343 & 38 \\
\hline Total number & 1063 & 100 & 514 & 100 & 1406 & 100 & 891 & 100 \\
\hline
\end{tabular}

Totally, the number of patients who address to orthodontist was decreased on $18 \%$. But, it should be noted that the number of children with dentofacial abnormalities are increased by 3.6 times during the period of milk bite.

The beginning of orthodontic treatment at early childhood corrects the malocclusion by functional methods and gives an opportunity to stimulation of jaws growth for eruption of permanent teeth and it realizes the possibility of non extraction of orthodontic correction.

Citizens with orthodontic complaints address to doctors in average by 2.5 times more often than rural people, teenagers and adults - by 5 times more often so the necessity of facial aesthetics contains urbanistic feature, so female patients address to orthodontist by 1.6 times.

Average number of people who are referred to the department of patients with permanent bite for recent 30 years in comparison with age categories contains $42.4 \%$. Dysfunction of temporomandibular joint is present in 70$75 \%$ of orthodontic patients [19]. The use of extraction of healthy teeth is applied for creating gap during abnormalities or teeth crowding.

The orthodontist in the modern world has large methods for the correction of dentofacial abnormalities. In the orthodontic treatment of patients of any age, the complex method is leading one, therefore the cooperation of orthodontists with dental surgeons is a daily clinical practice. However, a necessary condition for high-quality work of a modern orthodontist is competent diagnosis and an individual approach in treating each patient based on orthodontic treatment protocols.

The most difficult and discussable, both from the point of view of orthodontists and on the part of cooperation with patients, is the question of the extraction of healthy teeth. The issue about the choice of concrete teeth extraction is discussed.

This problem has been relevant for many decades.
During evolutionary mechanism of the adaptive variability of the human body, the anatomy of the dentition system of a modern person undergoes a significant reduction in the chewing load as compared to the primitive man, namely, the number of teeth changes, and cases of natural hypodontia are more common than supernumerary teeth.

However, in spite of the tactics of removing healthy teeth in the treatment of dental abnormalities, which has already become common in the world of orthodontic practice, the practicability of such surgical intervention is still a controversial issue in European scientific literature.

6318 posters of 11 European orthodontic congresses (1998-2014) were analyzed to understand the role of extraction therapy in orthodontic treatment.

Points of view of many orthodontists are discussable when they discuss the issue of treatment of dentofacial abnormalities. Some specialists recommend extraction method of treatment, others - non extraction.

In cycle of lectures "Orthodontics without teeth extraction" of Institute of Stomatology of Illinois (USA) recommends to use three necessary components: intense technique, palatine clasper, lip bumper.

Works related to the extraction of teeth for orthodontic reasons contain insignificant part - only 82 posters (1.3\%): 18 reports $(22 \%)$ include the main problem of the strategic choice of treatment method - extraction or nonextraction; $40(49 \%)$ are concerned with the removal of premolars; $15(18 \%)$ - removal of the first permanent molars; $6(7 \%)$ - extraction of the second and third molars in three posters $(4 \%)$ are discussed the removal of incisors in the lower jaw.

Presented qualitative correlation of scientific posters is indicative in clinical practice of orthodontists for extraction (Fig. 1).

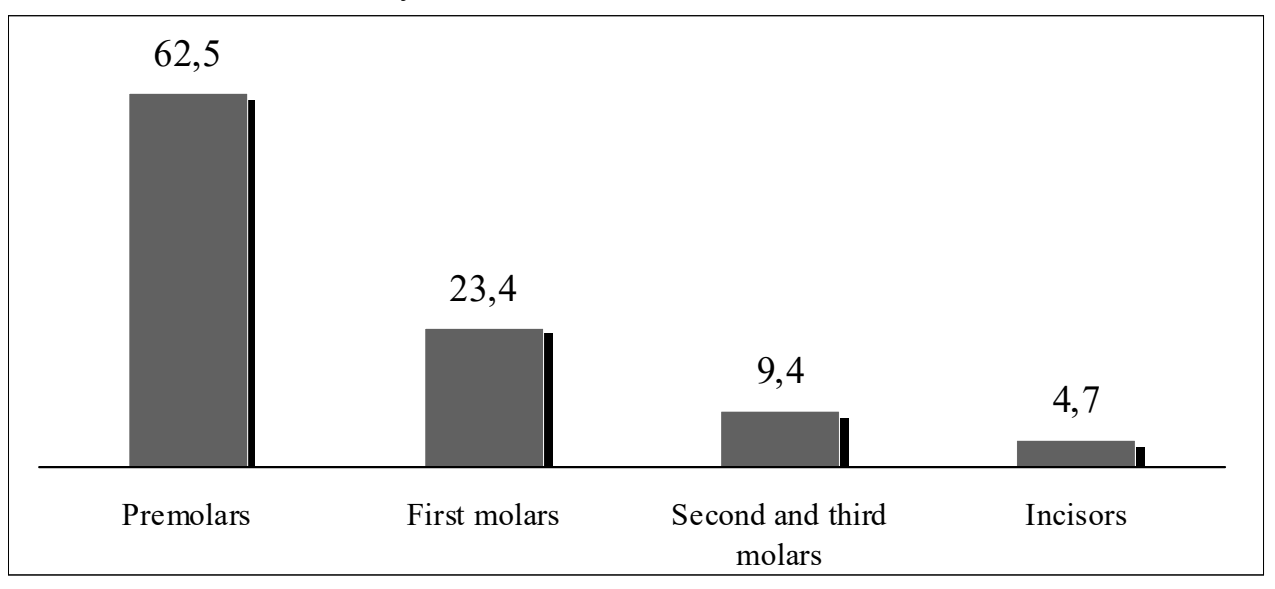

Figure 1. The choice of teeth for extraction by orthodontic indications (in \%) 
In clinics of Italy, treatment of extraction of some healthy teeth is applied in the third part of European patients [36]. More often Italian colleagues extract all first premolars $(20.7 \%)$ or the second premolars $(6.9 \%)$, and the lower incisor is extracted more rare than others $(1.2 \%)$.

Specialists' point of view of orthodontic treatment with extraction significantly changes and $\mathrm{W}$. Proffit this pendulum has not been stopped yet [35].

"The debates on removal are still alive" - this is how Spanish orthodontists begin their report, the aim of which is to determine which factors influence the choice of treatment with or without removal. The results of their study showed that the size of the teeth, age, mismatch of the dental arch to the basal, improper closing of the lips in meso- and brachiocephals are not all factors that increase the possibility of treatment with removal [9].

According to modern European concepts, the first premolars are the most frequent choice for orthodontic removal. We reviewed many aspects of the practicability of such a choice and made sure that this is a typical and already familiar type of removal in the treatment of crowded teeth, protrusion with I class according to Angle, and in some cases with camouflage class II and III with Angle [35].

Researchers of National University of Singapore consider that the direction and magnitude of dental changes within the dentition when extracting the first premolars depends on many factors before treatment: the degree of crowding of the teeth, the inclination angle of the incisors, the age and sex of the patients [37].

When premolars are removed in the treatment of dental abnormalities, changes in the parameters of the jaws are appeared: the length of the dental arches of both jaws is significantly reduced, the intermolar width is reduced, and the interfangular distance remains unchanged [25].

Besides, removal of healthy teeth by orthodontic indications changes the position or the inclination of other teeth. So, researchers from Singapore determined the insignificant distalization of lower incisors [37], and Turkish orthodontists consider that removal of lower first premolars leads to mesial displacement of the first lower molars and it does not affect the inclination of the third molars [7, 2]. However, the opposite opinion is found among European colleagues, namely: the removal of four first premolars improves the angle of inclination of the third molars [18]. In addition, there is a decrease in the dental arch, but the size of the upper respiratory tract remains unchanged [26]. Therefore, when planning the extraction of premolars, the position of not only the teeth, which limit the defect, but also of the adjacent ones should be assessed.

Treatment with removal of premolars has a different effect on the vertical parameters of the face. With the removal of premolars and mesial displacement of the molars, the occlusion is deepened and the anterior third of the face decreases, but Iranian scientists consider that the vertical dimensions remain the same or even slightly increase [15].

The basal angle and the angle of the lower jaw remain unchanged, the facial angle decreases, the profile of the face looks like node and more harmonious. Extraction of the first premolars leads to changes in soft tissues: the size of the tongue decreases, the thickness of the lips changes, which does not depend on gender [10], however with age, age-related changes occur in patients with class I pathology, orthodontically treated with tooth extraction, every 10 years the ratio between upper frontal teeth and lips decreases by $1 \mathrm{~mm}$, lips flatten, and $\angle$ ANL increases by $2^{\circ}$ [1]. Comparative analysis of the profile characteristics of orthodontic patients confirmed that extraction therapy should not be avoided, since aesthetic profile changes are minimal (without gender differences) both in the treatment with removal of premolars and in the treatment without extraction [31, 32, 28]. European orthodontists, evaluating patient profiles, did not find a detrimental effect on the aesthetics of orthodontic tooth extraction in adults [24]. However, the profile of orthodontic patients of Chinese nationality even improves significantly with the use of extraction therapy [38].

Observations of experienced clinicians largely confirm that extraction of teeth does not guarantee the stability of the result. However, Dutch authors argue that the treatment of crowded teeth without extraction, even of moderate severity, gives more relapses than a severe treatment with removal [20].

During the second half of the replaceable bite, orthodontists of Norway consider removing the first four premolars during orthodontic treatment reduces the possibility of further development of dental abnormalities by $87 \%$ and, very importantly, tends to long-term stability [12]. The evaluation of temporal parameters includes: treatment with removal (33.3 months) lasts on average 8.1 months longer compared with treatment without removal (25.2 months) [3].

During multiple extractions, crowding of lower incisors is observed in children in 5 years by Hotz.

In adults with skeletal forms of occlusion abnormalities of class III according to Angle, the best choice is the combined method of extracting teeth, namely 34 and 44 , 15 and 25 teeth, which, according to Turkish doctors, prevents relapses, and for skeletal and dental alveolar forms I and II classes - the removal of the first four or four second premolars.

According to orthodontists of the East, the decision of orthodontic treatment with the removal of individual healthy teeth should be based on modeling the rules of nature. So, anodontia of the second premolars has the highest frequency after the third molars, their removal simulates natural hypodontia, which is, in their opinion, the most acceptable [14].

Rare, but orthodontists extract the second permanent teeth: molars and incisors.

The removal of the first permanent molars is carried out more often than others due to their earlier destruction, which gives significant positive changes in the vertical and sagittal planes upon obtaining good function and aesthetics, does not affect the growth of the mandible [23], and only slightly changing the profile of soft tissues $[5,6]$.

An interesting study was conducted by Turkish orthodontists, comparing two monozygous twins with dentaltooth abnormalities of class I according to Angle, treated in different ways: premolar and molar extraction. In the case of premolar extraction, the profile has changed; therefore, if the aesthetics of the face is acceptable, then the removal of first molars should be a treatment option [33].

A number of studies have studied the effect of the removal of the first molars on the further eruption of the third ones. In the works of Swiss, Turkish and Portuguese scientists there are scientific reasons to consider that the extraction of the first molars in adults leads to the 
alignment of the second molars and the normal eruption of the third, by increasing the space for their eruption [22, 34, 21]. Relapses are possible after closing of postextraction space [21].

After the removal of the second upper molar, the third erupts in $99.2 \%$, (average eruption time is 4.5 years), however, $33 \%$ do not have good occlusion, which requires additional correcting [17], with time the angle of inclination of the third molar improves after the second molar is removed that gives chances for eruption [39].

Extraction of a single mandibular incisor can be an alternative to the removal of four premolars, which gives minimal changes in the dental arches, the soft tissue profile and the stability of the results $[4,27,16]$. To make such a decision, all factors must be evaluated: the nature of the occlusion, the patient's complaints, the nature of growth, the condition of the teeth and periodontal disease and, most importantly, the experience of a specialist [11].

Criteria of tooth have not been determined yet. The need for ultimate clarification is indicated by many authors.

To solve the important issue of removing teeth for orthodontic reasons, an accurate individual diagnosis is needed based on the clinical picture, morphometric analysis of clinical and diagnostic jaw models and a detailed analysis of the teleroentgenograms [29]. To make a decision about the extraction of teeth in the process of orthodontic treatment, Japanese scientists from the University of Osaka offered a mathematical model, the program of which consists of 16 orthodontic measurements of clinical and diagnostic jaw models and 9 measurements of teleroentgenograms [13].

Orthodontic treatment cannot be standard, it can be individual for each patient [30].

Brazilian scientists use atypical or asymmetric extraction of teeth in their work, considering that it can be a rational solution for obtaining adequate occlusion and satisfactory aesthetics [29]. Turkish orthodontists presented two successful cases of asymmetric premolar extractions in patients with bite class II Angle bite, which once again confirms the need for an individual approach in each clinical case [8].

\section{Conclusions}

Thus, a modern approach to planning orthodontic treatment with removal of individual teeth requires consideration of the individual characteristics of each patient and a variety of factors: diagnosis (skeletal and dental alveolar), aesthetic characteristics of the face, functional state of the maxillofacial area, such as jaw growth, the state of hard dental tissue, periodontal conditions, etc.

The correct choice of teeth to be removed allows achieving multiple stable contacts and normalization of the function and aesthetics of the maxillofacial area, and, therefore, the predicted stable result of orthodontic treatment.

\section{References}

1. Akyalgin S, Hazar S, Guneri P, Gogii S. Extraction versus non-extraction: an evaluation by digital subtraction radiography. 82 Congress of the European Ortodontic Society; 2006 July 4-8; Vienna, Austria. Vienna; EOS; 2006. p. 55

2. Arun T, Nalbantgil N, Isik F, Erdem S, Ozpar R. Effect of premolar extractions on the eruption angle of mandibular third molars. 82 Congress of the European Ortodontic Society; 2006 July 4-8; Vienna, Austria. Vienna; EOS; 2006. p.133

3. Bjering R, Midtb M, Birkeland K, Vandevska-Radunovic V. Stability of non-extraction treatment 10 years out of reten- tion. 90 Congress of the European Ortodontic Society; 2014

4. Bohater M, Matthews T, Antoszewska J, Downarowicz P Kawala B. Comparison of Therapy in Adult Subjects with Crowded Anterior Teeth - Single Incisor Expansion, Proclination or Extraction? 85 Congress of the European Ortodontic Society; 2009 June 10-14; Helsinki, Finland. Helsinki; EOS; 2009. p. 49-50

5. Booij H, Stalpers M, Kuijpers-Jagtman A. M, Katsaros C Extraction of maxillary first molars in class II division 1 paients. 84 Congress of the European Ortodontic Society; 2008 June 10-14; Lisbon, Portugal. Lisbon; EOS; 2008. p. 54

6. Cudovic B, Schneider-Del Savio T. A long term assessment of vertical dimension and occlusal relationship in orthodontic diagnosis requiring the extraction of (all) fist molars. 81 Congress of the European Ortodontic Society; 2005 June 3-7; Amsterdam, The Netherlands. Amsterdam; EOS; 2005.

7. Cura N, Ozta $E$, Gill A. Influence of premolar extractions on the position of the lower third molars. 75 Congress of the European Ortodontic Society; 1999 June 23-26; Strasbourg, France. Strasbourg; 1999

8. DemirAktop P, Alcan T. Asymmetric premolar extractions in patients with class ii subdivision malocclusions: two case reports. 88 Congress of the European Ortodontic Society; 2012 June 18-23; Santiago de Compostela, Spain; EOS; 2012. p. 297-8

9. Eliseo Palencia. Modelling extraction decision making. 88 Congress of the European Ortodontic Society; 2012 June 18-23; Santiago de Compostela, Spain; EOS; 2012. p. 19

10. GuarizaFilho O, Abrao J, Soft tissue profile changes resulting from orthodontic treatment with extractions. 75 Congress of the European Ortodontic Society; 1999 June 23-26; Strasbourg, France. Strasbourg; 1999

11. GuarizaFilho O, Tanaka O, Essenfelder L R C, Maruo H The dilemma of congenitally missing mandibular incisors. 75 Congress of the European Ortodontic Society; 1999 June 23-26; Strasbourg, France. Strasbourg; 1999

12. Gjethammer M. R, Midtbo M, Boe O. E. Long-term outcome and stability in treated class I extraction and nonextraction patient. 86 Congress of the European Ortodontic Society; 2010 June 15-19; Portoroz, Slovenia. Portoroz; EOS; 2010. p. 97

13. Horiguchi E, Yagi M, Takada K. Mathematical modelling of orthodontic tooth extraction and non-extraction decisions. 82 Congress of the European Ortodontic Society; 2006 July 4-8; Vienna, Austria. Vienna; EOS; 2006. p. 92

14. Jarrah L, Jarrah H. Evidence based extraction. 84 Congress of the European Ortodontic Society; 2008 June 1014; Lisbon, Portugal. Lisbon; EOS; 2008. p.127

15. Kashani M. A, Neishabori A. The effect of quadrilateral first premolar extractions on vertical occlusal dimensions. 79 Congress of the European Ortodontic Society; 2003 June 10-14; Prague, Czech Republic. Prague; EOS; 2003 p. 530-531

16. Kaya B, Erken S, Polat-Ozsoy O. Dentofacial effects of lower incisor and four premolar extractions. 87 Congress of the European Ortodontic Society; 2011 June 19-23; Istanbul, Turkey; EOS; 2011. p. 98

17. Kim K, Chung C, Kim I, Yoon H. Factors that Affect Maxillary Third Molar Eruption after Maxillary Second Molar Extraction. 85 Congress of the European Ortodontic Society; 2009 June 10-14; Helsinki, Finland. Helsinki; EOS; 2009. p. $119-120$

18. Kocadereli I, Saysel M.Y, Meral G.D, Tasar F. The effects of fist premolar extractions on third molar angulation. 81 Congress of the European Ortodontic Society; 2005 June 3-7; Amsterdam, The Netherlands. Amsterdam; EOS; 2005.

19. Kuroedova V. D, Stasiuk A. A, Makarova A. N, Trofimenko K. L, Vyzhenko E. E. Symmetry of elements of temporomandibular joint. Medicinal sheets, 2017; 70(6):10791082.

20. Kuitert $R$, Zentner A. Influence of retention time, postretention time and extractions on relapse of incisor crowding. 87 Congress of the European Ortodontic Society; 2011 June 19-23; Istanbul, Turkey; EOS; 2011. p. 225 
21. Leitao P. Why not extract first molars? 82 Congress of the European Ortodontic Society; 2006 July 4-8; Vienna, Austria. Vienna; EOS; 2006. p. 57

22. Livas C, Halazonetis D, Booij J. W, Katsaros C. Maxillary Second and third molar inclination after extraction of the first molars in class II division 1 subjects. 86 Congress of the European Ortodontic Society; 2010 June 15-19; Portoroz, Slovenia. Portoroz; EOS; 2010. p. 122

23. Lindstrand C, Brattström V, Odenrick L. Mandibular growth after extraction of lower first molars. A longitudinal study. 75 Congress of the European Ortodontic Society; 1998 June 2-7; Mainz, Germany. Mainz; EOS; 1998

24. Lodice G, Laino G, Ammendola L, Danzi G, Capuozzo R. The impact of extraction and non-extraction treatment on facial aesthetics and smile attractiveness. 88 Congress of the European Ortodontic Society; 2012 June 18-23; Santiago de Compostela, Spain; EOS; 2012. p. 235-236

25. Lonescu E, Grigore R, Balanescu A. M, Teodorescu E, Lonbescu I. Extraction versus non-extraction: dimensional changes of the dental arches. 87 Congress of the European Ortodontic Society; 2011 June 19-23; Istanbul, Turkey; EOS; 2011. p. 373

26. Maaitah E. Al, Alhaija E. Abu, SaidN. E. Effects of first premolar extractions on upper airway dimensions in bimaxillaryproclination patients. 88 Congress of the European Ortodontic Society; 2012 June 18-23; Santiago de Compostela, Spain; EOS; 2012. p.152

27. Macri L. A, Golini S, Lucarelli E, Savone M, Oliva B. Mandibular incisor extraction: is it an evidence-based therapeutic decision? 82 Congress of the European Ortodontic Society; 2006 July 4-8; Vienna, Austria. Vienna; EOS; 2006. p. 119

28. Maselli A, Greco M, Amadori C. Soft tissue changes in class II division 1 subjects treated with and without extractions. 82 Congress of the European Ortodontic Society; 2006 July 4-8; Vienna, Austria. Vienna; EOS; 2006. p. 55

29. Matsui R. H, Melo Castilho J. C, Leonelli de Moraes M. E, De Moraes L. C, Medici Filho E. Orthodontic treatment with asymmetric extractions. 84 Congress of the European Ortodontic Society; 2008 June 10-14; Lisbon, Portugal. Lisbon; EOS; 2008. p. 179

30. Mesaros M. F, Muntean A, Rodica J, Ogodescu A, Mesaros A-S. Criteria used in choosing which teeth to extract for orthodontic purposes. 84 Congress of the European
Ortodontic Society; 2008 June 10-14; Lisbon, Portugal. Lisbon; EOS; 2008. p. 190

31. Muntean A, Glavan F, Bratu E, Jianu R, Szuhanek C. Aesthetic changes of the profile in extraction and sonextraction cases. 86 Congress of the European Ortodontic Society; 2010 June 15-19; Portoroz, Slovenia. Portoroz; EOS; 2010. p. 81

32. Nebioglu-Dalci 0, Altug-Atac A, Aydemir H, ToygarMemikoglu U. Extraction versus non-effects on the soft tissues in II, division 2 subjects. 84 Congress of the European Ortodontic Society; 2008 June 10-14; Lisbon, Portugal. Lisbon; EOS; 2008. p. 76

33. Ozer M, Aras S, Arid B. Soft tissue profile changes following premolar and molar extraction: a comparison of monozygotic twins. 82 Congress of the European Ortodontic Society; 2006 July 4-8; Vienna, Austria. Vienna; EOS; 2006. p. 143

34. Ozer M, Arici S, Bayram M. Does orthodontic treatment change third molar position and eruption space? 81 Congress of the European Ortodontic Society; 2005 June 3-7; Amsterdam, The Netherlands. Amsterdam; EOS; 2005.

35. Proffit W. R. Contemporary Orthodontics. 4th ed. Moscow. Medpress-inform; 2008. p. 560.

36. Rapuano A, Fiorentino G, D'Angelo G. Frequency and consistency of orthodontic extraction decisions between examiners with different clinical experience. 81 Congress of the European Ortodontic Society; 2005 June 3-7; Amsterdam, The Netherlands. Amsterdam; EOS; 2005.

37. Wee E C K, Ong S H, Lim A C Y, Lim K F, Foong K W C. Effect of pre-treatment parameters on three-dimensional dental changes with premolar extractions. 87 Congress of the European Ortodontic Society; 2011 June 19-23; Istanbul, Turkey; EOS; 2011. p. 131

38. Xu T-M, Liu Y, Yang M-Z. Comparison of extraction versus non-extraction orthodontic treatment. 82 Congress of the European Ortodontic Society; 2006 July 4-8; Vienna, Austria. Vienna; EOS; 2006. p. 72-73

39. Yoon H, Chang I, Hwang S, Kim K. Occlusal Evaluation of Maxillary Third Molars after Maxillary Second Molar Extraction. 85 Congress of the European Ortodontic Society; 2009 June 10-14; Helsinki, Finland. Helsinki; EOS; 2009. p. 119

Матеріал надійшов до редакції 08.04.2019 p. 